\title{
ANALISIS FAKTOR PERSONAL PADA SUMBER KOMUNIKASI DALAM PENGELOLAAN TANAMAN OBAT KELUARGA DI JAWA BARAT
}

\author{
Iriana Bakti, Evie Ariadne Shinta Dewi, Rosnandar Romli, Heru Ryanto Budiana \\ Program Studi Hubungan Masyarakat, Fakultas Ilmu Komunikasi, Universitas Padjadjaran
}

\begin{abstract}
ABSTRAK
Penelitian ini didasarkan pada upaya pemerintah melakukan penyebarluasan informasi tentang tanaman obat melalui saluran interpersonal dengan tujuan untuk membangun partisipasi masyarakat dalam pengelolaan tanaman obat. Tujuan Penelitian adalah untuk mengetahui faktor: biologis, sosiopsikologis, dan sosiogenis yang melekat pada diri narasumber (komunikator). Metode yang digunakan dalam penelitian ini adalah metode deskriptif yang menggambarkan masalah berdasarkan sifat data kualitatif sehingga dapat diperoleh pemahaman yang lebih mendalam tentang masalah yang diteliti. Hasil penelitian menunjukkan bahwa ternyata narasumber (komunikator) memiliki posisi penting sebagai salah satu komponen komunikasi yang dapat membangun efektivitas komunikasi interpersonal dengan anggota masyarakat. Pentingnya keberadaan narasumber ini dapat dilihat dari faktor biologis yang meliputi alasan mengelola toga karena sesuai dengan latar belakang pendidikan, dan tugas pokok dan fungsi pekerjaan yang digelutinya. Adapun dilihat dari faktor sosiopsikologis, narasumber menyatakan toga dapat dimanfaatkan oleh masyarakat untuk pertolongan pertama terhadap masalah kesehatan, bisa menjadi salah satu sumber pendapatan masyarakat, menjadikan pekarangan rumah indah, mengurangi biaya pengeluaran keluarga untuk obat, dan bisa dibuat makanan olahan, misalnya kripik bayem. Sedangkan faktor sosiogenis menanam toga bukan pengalaman baru, masyarakat merespon positif, sesuai dengan bidang ilmu, dan menjadi jaminan dalam bertugas.
\end{abstract}

Kata-kata kunci: Faktor biologis, sosiopsikologis, sosiogenis, komunikator, pengelolaan tanaman obat keluarga (toga)

\section{PERSONAL FACTOR ANALYSIS ON THE COMMUNICATION SOURCE IN FAMILY MEDICINE PLANT MANAGEMENT IN WEST JAVA}

\begin{abstract}
This study based on the government's efforts to disseminate information about medicinal plants through interpersonal channels with the aim to build community participation in the management of medicinal plants. The purpose of this research is to identify factors: biological, sociopshycological, and sociogenical inherent in resource (communicator). The method used in this research is descriptive method that describes the nature of the problem based on qualitative data, to obtain a deeper understanding of the problem. The results show that in fact, a resource (communicator) has an important position as one of the components of communication that can build an effective interpersonal communication with community members. The importance of the existence of this resource can be viewed from the biological factors that include the reasons for managing family madicinal plants (toga) according to educational background, and the duties and functions of the job that they do. As seen from sociopshycological factors, informants expressed a toga can be used by the public for the first aid to health problems, may be one source of income of the people, making the yard beautiful, reducing expenses for the family of drugs, and can be made processed foods, such as crispy spinach. While the sociogenesis factors include planting toga is not a new experience, people responded positively, accordance with science, and a guarantee in charge.
\end{abstract}

Keywords: Biological, sociopshycological, sociogenical factors, communicators, family medicine plant management

Korespondensi: Dr. Iriana Bakti, M.Si. Program Studi Hubungan Masyarakat, Fakultas Ilmu Komunikasi, Universitas Padjadjaran, Jl. Raya Bandung-Sumedang Km.21.Email: irianabaktipr@gmail.com 


\section{PENDAHULUAN}

Salah satu permasalahan yang sedang dihadapi oleh masyarakat Indonesia saat ini adalah tingginya harga obat kimia sehingga menyebabkan banyak masyarakat kesulitan untuk membelinya dan efek samping yang ditimbulkannya dalam jangka panjang. Untuk menghadapi masalah tersebut, pemerintah membuat kebijakan untuk melakukan gerakan kembali ke alam atau back to nature berupa penggunaan obat tanaman atau herbal. Pemerintah dalam mengimplementasikan pemasyarakatan tanaman obat melakukan upaya penyebarluasan informasi tentang tanaman obat, diantaranya melalui saluran interpersonal dengan tujuan untuk membangun kesadaran masyarakat terhadap pengelolaan tanaman obat.

Berdasarkan hasil penelitian sebelumnya, model pencarian informasi yang terdiri dari faktor sumber informasi berpengaruh terhadap kesadaran masyarakat dalam pengelolaan tanaman obat. Namun demikian, walaupun sumber informasi memiliki pengaruh dalam pengelolaan tanaman obat, terdapat kendala interpersonal ketika anggota masyarakat berinteraksi dengan narasumber saat melakukan pencarian informasi. Kendala tersebut diantaranya terkait dengan status sosial narasumber yang relatif lebih tinggi, dan kendala lingkungan yang berasal dari lingkungan sekitar individu pencari informasi, misalnya fasilitas yang membatasi akses informasi, alur pencarian informasi yang rumit, waktu yang lama dalam mengakses informasi, dan sebagainya.

Berdasarkan hasil penelitian tersebut, untuk selanjutnya diperlukan penelitian tentang faktor personal narasumber yang terdiri dari faktor biologis, faktor sosiopsikologis dan faktor sosiogenis. Berdasarkan paparan dalam latar belakang masalah tersebut, rumusan masalah pada penelitian ini yaitu "Bagaimana faktor personal yang dimiliki narasumber dalam mengelola tanaman obat". Masalah dalam penelitian ini dapat diidentifikasi sebagai berikut: (1) Bagaimana faktor biologis narasumber pada pengelolaan tanaman obat?, (2) Bagaimana faktor sosiopsikologis narasumber pada pengelolaan tanaman obat?, dan (3) Bagaimana faktor sosiogenis narasumber pada pengelolaan tanaman obat? Adapun tujuan dari penelitian ini adalah untuk mengetahui: (1) Faktor biologis narasumber pada pengelolaan tanaman obat, (2) Faktor sosiopsikologis narasumber pada pengelolaan tanaman obat, dan (3) Faktor sosiogenis narasumber pada pengelolaan tanaman obat.

Penelitian ini diharapkan dapat memberikan kontribusi bagi pihak-pihak terkait yang terlibat dalam proses komunikasi bagi petugas dari dinas terkait. Penelitian ini juga diharapkan dapat memberi kontribusi sebagai masukan bahwa faktor personal dan sosial narasumber dapat menentukan efektivitas komunikasi yang dilakukannya. Bagi masyarakat, kehadiran narasumber sebagai komunikator dapat mempermudah dirinya dalam menerima informasi karena terdapat kesamaan pandangan tentang manfaat tanaman obat sehingga di antara kedua belah pihak dapat terjalin kerja sama yang diimplementasikan dalam bentuk partisipasi masyarakat dalam mengelola tanaman obat.

\section{METODE PENELITIAN}

Penelitian ini menggunakan metode deskriptif dengan menggunakan data-data kualitatif untuk mendapatkan pemahaman yang lebih lengkap tentang masalah yang diteliti. Berdasarkan sifat data ini, masalah penelitian dapat dipahami setelah melakukan konfirmasi data kualitatif yang diperoleh dari deskripsi hasil wawancara dengan informan.

Subjek penelitian ini terdiri dari narasumber yang berkutat dalam pengelolaan tanaman obat, baik peneliti, pembina, maupun penyuluh tanaman obat yang berdinas di instansi terkait. Adapun yang menjadi objek penelitiannya menyangkut faktor personal yang melekat pada diri narasumber, terdiri dari faktor biologis, sosiopsikologis dan sosiogenis yang berpengaruh pada caranya berperilaku ketika dirinya berinteraksi dengan masyarakat.

Narasumber yang dijadikan informan dalam penelitian ini dipilih berdasarkan kriteria; (1) Subjek penelitian bersedia menerima kehadiran peneliti, (2) Berkemampuan dan berkemauan untuk mengutarakan pengalaman-pengalaman masa lalu dan masa sekarang, dan (3) Memiliki pengalaman yang menarik, misalnya memiliki 
pengalaman yang khusus.

Teknik pengumpulan data yang dilakukan dalam penelitian ini adalah observasi, wawancara, dan studi dokumentasi. Observasi dilakukan dengan mengamati langsung aktivitas yang dilakukan masyarakat ketika sedang berdialog dengan petugas dari dinas terkait, wawancara mendalam dengan informan yang relevan dengan masalah yang diteliti, dan studi dokumentasi berupa pencarian informasi yang berkaitan dengan masalah yang relevan dengan penelitian.

Analisis data dilakukan secara deskriptif dengan menuturkan dan menafsirkan data tentang keadaan informan sehingga dapat diperoleh gambaran yang riil tentang faktor personal dan faktor situasional yang mendasari pengelolaan tanaman obat yang dilakukannya bersama masyarakat.

\section{HASIL DAN PEMBAHASAN}

Penelitian ini dilakukan melalui wawancara mendalam terhadap 7 orang informan yang sering terlibat dalam pengelolaan tanaman obat keluarga. Mereka terdiri dari petugas dari dinas terkait dan ketua kelompok petani tanaman obat di Kota Bogor, Kabupaten Sukabumi, Kabupaten Sumedang, Kabupaten Bandung, Kabupaten Subang, dan Kabupaten Kuningan. Adapun yang dijadikan objek wawancaranya meliputi faktor personal yang melekat pada diri informan.

Berdasarkan hasil penelitian, faktor personal yang melekat pada informan terdiri dari berupa faktor biologis, faktor sosiopsikologis, dan faktor sosiogenis yang berkaitan dengan tanaman obat. Hasil penelitian dapat dilihat dari pendapat yang disampaikan oleh narasumber sebagai berikut:

Pertama, faktor biologis. Nurliani menyatakan "alasan menjadi narasumber dalam pengelolaan tanaman obat adalah tugas pokok dan fungsi sebagai pegawai Balai Penelitian Tanaman Rempah dan Obat (Balitro)'.' Sementara itu menurut Seni, menjadi narasumber dalam pengelolaan tanaman obat "karena sesuai dengan latar belakang pendidikan (SPMA)".

Hal senada disampaikan oleh Arto yang menyatakan alasan menjadi narasumber pengelolaan tanaman obat: "Awalnya tertarik menjadi penyuluh karena latar belakang pendidikan di SPMA Bogor dan di Fakultas Pertanian Unwim, dan setelah bekerja menjadi tugas dan kewajiban sebagai penyuluh pendamping.....". Alasan yang sama dikemukakan oleh Dedeh: "alasan menjadi narasumber dalam pengelolaan tanaman obat karena sesuai dengan jurusan di SPMA".

Lendy Hedidiana menyatakan: "Karena tanaman toga bermanfaat sebagai tanaman obat, toga juga bisa membuat suasana halaman rumah menjadi asri, sejuk dan indah"....saya ditugaskan untuk menjelaskan ke masayarakat". Parida Triyani menyatakan: "Toga sangat penting bagi kebutuhan keluarga jadi harus disosialisasikan"

Lain halnya dengan Agus Carman yang menyatakan: "Sebagai seorang penyuluh pertanian tujuan nya adalah meningkatkan kesejahteraan petani, dengan memanfaatkan pekarangan rumah dengan obat keluarga sedikit nya dapat membantu keluarga untuk menyediakan obat alternatif sehingga tidak usah membeli obat kimia".

Kedua, faktor psikologis. Nurliani memperkenalkan toga sebagai narasumber kepada masyarakat melalui pelatihan maupun dalam berbagai event (seminar, wawancara dengan wartawan majalah, TV, Radio), dan mempublikasikan hasil penelitian baik pada jurnal ilmiah primer atau semi popular. Adapun sikap Nurliani terhadap tanaman obat disampaikannya sebagai berikut:

"Toga diharapkan dapat dimanfaatkan oleh masyarakat untuk pertolongan pertama terhadap masalah kesehatan, bisa menjadi salah satu sumber pendapatan masyarakat, menjadikan pekarangan rumah indah, mengurangi biaya pengeluaran keluarga untuk obat. Selain manfaat kesehatan, TOGA juga bisa menjadi sumber pangan karena tanaman obat memiliki kandungan gizi seperti vitamin, mineral, protein, karbohidrat dll."

Selanjutnya Nurliani menyatakan toga didefinisikan sebagai taman obat keluarga. Dalamhalinidiartikansebagailahan pekarangan/ sekitar rumah yang ditanami tanaman obat 
dengan memperhatikan aspek estetika dan berfungsi sebagai apotek hidup (menyediakan obat bagi keluarga). "Jenis tanaman obat yang ditanam sebaiknya merupakan tanaman yang diperlukan untuk mengatasi masalah kesehatan yang umum (diare, batuk, pilek, demam, dll), banyak ditemukan di sekitar rumah, mudah pemeliharaanya, dll.".

Sementara itu, sikap Seni terhadap tanaman obat:

"Toga bagus dan bisa dijadikan pertolongan pertama di rumah kalau ada yang sakit, juga bisa dibuat makanan olahan, misalnya kripik bayem". Toga adalah tanaman obat keluarga yang bisa dipake buat pengobatan di rumah kalau ada yang sakit, oleh karena itu langkah-langkah yang dilakukan dalam pengelolaan toga dengan membantu penyuluh senior menyiapkan materi penyuluhan, ikut hadir dalam pertemuan gapoktan, ikut menanam toga bersama warga, dan ikut memanen dan membuat makanan olahannya bersama warga"

Sikap Arto terhadap tanaman obat keluarga: "Toga itu sangat bermanfaat bagi masyarakat terutama untuk memenuhi kebutuhan gizi keluarganya dengan memetik sendiri dari pekarangan. Toga sangat bermanfaat sebagai obatobatan keluarga yang mudah didapat juga aman dikonsumsi. Saya juga memberi penjelasan, penyuluhan, dan pendampingan tentang toga, juga membuat Kebun Bibit Contoh di desa. Selanjutnya Arto mengartikan toga dengan menjelaskan, bilamana ada kejadian, seperti kecelakaan kecil di rumah, jatuh atau tergores, tidak perlu beli obat ke warung, atau sebelum dibawa ke rumah sakit, cukup memetik toga di halaman.."

Untuk mengimplementasikan pengelolaan toga, Arto melakukan langkah-langkah berupa menyampaikan informasi kepada ibu-ibu tentang manfaat toga, kemudian membagikan bibit untuk ditanam, mengajari cara menanamnya, memetik hasil bersama ibu-ibu, dan memberi tahu waktu penyemaiannya".
Sikap Dedeh terhadap tanaman obat keluarga:

“ Toga bermanfaat bagi keluarga, karena murah dan mudah, jadi gak usah beli di warung.... Toga sangat bermanfaat bagi masyarakat untuk menambah gizi, tapi bagi yang belum tahu, masyarakat males menanam toga di pekarangannya, karena pekarangannya lebih indah kalau diisi tanaman hias".

Sikap Lendy Hedidiana:

"Menurut saya tanaman obat keluarga (toga) sangat baik untuk dikembangkan karena sangat bermanfaat untuk keluarga. Menurut saya tanaman obat keluarga (toga) sangat baik untuk dikembangkan karena sangat bermanfaat sebagai pertolongan pertama bagi keluarga, toga biasannya ditanam dikebun ataupun halaman rumah. Jenis yang ditanam biasanya tanaman obat yang biasa dimanfaatkan daun, batang, buah, biji, akar dan umbi atau rimpang. Yang biasa dilakukan adalah pemeliharaan, penyiraman, pemupukan, dan pemangkasan. Hal ini dimaksudkan agar toga tumbuh dengan baik".

Parida Triyani menyatakan:

"Toga sangat dibutuhkan bagi masyarakat. Toga adalah hasil budidaya yang berfungsi sebagai obat, fungsi toga sebagai pengganti obat kimia. Toga dikelola secara individu yang dibudidayakan dalam pekarangan rumah".

Lain halnya dengan sikap Agus Carman yang menyatakan:

"Sangat bermanfaat dibanding menanam tanaman hias yang tidak ada khasiatnya. Toga adalah tanaman obat keluarga. Jenisnya beraneka ragam. Ada yang berupa tanaman menjalar, perdu, pohon dan lain sebagainya, fungsinya sebagai obat alternatif (herbal). Langkah awal adalah pengenalan tentang toga itu sendiri, apa itu toga dan manfaat toga sehingga diharapkan masyarakat berminat untuk mengelola pekarangan nya dengan tanaman toga".

Ketiga, faktor sosiogenis. Menurut 
Nurliani:

"Keterlibatan dalam pengelolaan toga sudah cukup lama sejak tahun 1995 bukan pengalaman baru. Selama melakukan pembinaan, masyarakat merespon dengan baik dalam bentuk pertanyaan, berbagi pengalaman tentang masalah kesehatan dan pemanfaatan tanaman obat untuk mengatasi masalah penyakit, merespon dengan menanam tanaman obat, dan bahkan memberitahukan/ mengajak tetangga untuk aktif menanam tanaman obat". Selanjutnya ia mengatakan sudah menjadi kewajiban untuk mendiseminasikan hasil penelitian kepada masyarakat, karena sesuai dengan bidang yang digeluti selama ini”.

Seni menyatakan "Keterlibatan dalam pengelolaan toga bukan pengalaman baru, karena sudah 5 tahun jadi penyuluh, masyarakat semangat kalau diajak menanam toga, juga sesuai dengan bidang saya sebagai penyuluh, dan ini merupakan jaminan bahwa saya telah menjalankan kegiatan yang sesuai".

Sementara Arto mengatakan:

"Bukan pengalaman baru, karena sudah 30 tahun bekerja sebagai penyuluh. Saya juga berharap dari toga ini masyarakat tidak hanya konsumsi sendiri tetapi bisa juga dijual sehingga bisa mendapat tambahan pendapatan untuk keluarganya. Kami sekarang sedang mencoba menularkan kecintaan menanam toga tidak hanya pada ibuibu, tetapi pada anak-anak.... kegiatan ini berkaitan, karena status saya adalah penyuluh pendamping pertanian ketahanan pangan, dan ini merupakan jaminan bahwa saya telah melaksanakan tugas yang sesuai dengan bidang saya".

Adapun Dedeh mengatakan:

"Keterlibatan dalam pengelolaan toga merupakan pengalaman baru (2 tahun), dan masyarakat antusias menanam toga kalau sudah diberi penjelasan oleh kami. Biasanya masyarakat harus diberi contoh, kalau sukses baru mereka mau menanam toga. Keterlibatan dalam pengelolaan toga sesuai dengan bidang ilmu saya di SPMA, dan terjamin kegiatan ini karena sesuai dengan latar belakang pendidikan".

Lendy Hedidiana menyatakan:

"Keterlibatan dalam pengelolaan toga tidak baru, karena sebelumnya juga sudah menanam tanaman yang berfungsi sebagai obat-obatan hanya saja ragam jenis yang ditanam masih sedikit. Saya berharap masyarakat merespon dengan baik dan mau melaksanakan atau membudidayakan tanaman obat keluarga ini. Saya bekerja di bidang pertanian, dan salah satu programnya yaitu pemanfaatan lahan pekarangan rumah, diantaranya ditanami toga".

Parida Triyani menyatakan "Keterlibatan dalam pengelolaan toga merupakan pengalaman baru. Masyarakat merespon dengan baik, selanjutnya mampu melaksanakan budidaya toga. Keterlibatan di toga juga sesuai dengan bidang dan menjadi jaminan sesuai dengan pekerjaan".

Agus Carman yang menyatakan "Mengelola toga merupkan hal baru. Tentunya harapannya direspon dengan baik, selanjutnya apa yang dilatihkan diterapakan sedikitnya ada kaitan, tentang pemanfaatan pekarangan. Secara umum ya".

Berdasarkan wawancara dengan informan di atas, hasilnya dapat di klasifikasikan dalam tabel di halaman berikut ini.

Berdasarkan hasil wawancara dengan para informan di atas, maka hasil penelitian tentang faktor personal narasumber dalam pengelolaan toga dapat dikategorikan dalam tiga faktor yaitu faktor Biologis (sesuai dengan tugas pokok dan fungsi, dan sesuai dengan latar belakang pendidikan), faktor Sosiopsikologis (dapat dimanfaatkan untuk pertolongan pertama, sumber pendapatan, dan sumber pangan, dapat dimanfaatkan sebagi sumber gizi keluarga, dan toga harus disosialisasikan), serta faktor Sosiogenis (toga bukan merupakan pengalaman baru, respon positif, antusias tinggi, sesuai dengan bidang ilmu, dan menjadi jaminan dalam bertugas). 
Tabel 1 Faktor Personal Narasumber Terhadap Pengelolaan Tanaman Obat keluarga

\begin{tabular}{llll}
\hline Faktor Personal & Biologis & Psikologis & Sosiopsikologis \\
\hline Nurliani & $\begin{array}{l}\text { Sesuai tugas pokok, } \\
\text { dan fungsi }\end{array}$ & $\begin{array}{l}\text { Pertolongan pertama, } \\
\text { sumber pendapatan, } \\
\text { kebutuhan gizi }\end{array}$ & $\begin{array}{l}\text { Bukan pengalaman } \\
\text { baru, sesuai dengan } \\
\text { bidang ilmu }\end{array}$ \\
\hline Seni & $\begin{array}{l}\text { Sesuai dengan latar } \\
\text { belakang pendidikan }\end{array}$ & Pertolongan pertama & $\begin{array}{l}\text { Bukan pengalaman } \\
\text { baru, sesuai dengan } \\
\text { bidang ilmu }\end{array}$ \\
\hline Arto & $\begin{array}{l}\text { Sesuai Tugas pokok, } \\
\text { dan Fungsi }\end{array}$ & Kebutuhan gizi & $\begin{array}{l}\text { Bukan pangan menjadi jaminan } \\
\text { dalam tugas }\end{array}$ \\
\hline Dedeh & $\begin{array}{l}\text { Sesuai dengan latar } \\
\text { belakang pendidikan }\end{array}$ & Kebutuhan gizi & $\begin{array}{l}\text { Antusias tinggi, sesuai } \\
\text { dengan bidang ilmu }\end{array}$ \\
\hline Lendy Hedidiana & $\begin{array}{l}\text { Sesuai dengan tugas } \\
\text { pokok, dan fungsi }\end{array}$ & Pertolongan pertama & $\begin{array}{l}\text { Menjadi jaminan } \\
\text { dalam tugas }\end{array}$ \\
\hline Parida Triyani & $\begin{array}{l}\text { Sesuai dengan tugas } \\
\text { pokok dan fungsi }\end{array}$ & Pertolongan pertama & Respon positif \\
\hline \multirow{2}{*}{ Agus carman } & $\begin{array}{l}\text { Sesuai dengan tugas } \\
\text { pokok dan fungsi }\end{array}$ & $\begin{array}{l}\text { Pertolongan pertama, } \\
\text { harus disosialisasikan }\end{array}$ & Respon positif \\
\hline
\end{tabular}

Komunikasi merupakan proses penyampaian informasi dari komunikator kepada komunikan. Komunikasi dikatakan efektif apabila disampaikan oleh komunikator yang memiliki keahlian dan kepercayaan dihadapan komunikan. Seorang komunikator yang dalam hal ini adalah narasumber yang berperan sebagai peneliti, pembina, dan penyuluh berusaha melakukan aktivitas komunikasi dalam kaitannya dengan pengelolaan tanaman obat. Keadaan diri (faktor personal), baik yang berkaitan dengan faktor biologis, sosiopsikologis, dan sosiogenis narasumber sangat penting karena berkaitan dengan perilaku komunikasinya ketika dirinya berinteraksi dengan masyarakat.

Berdasarkan hasil penelitian, faktor biologis narasumber berkaitan dengan motif melakukan pengelolaan tanaman obat, yaitu sesuai dengan tugas, pokok, dan fungsi (tupoksi), serta latar belakang pendidikannya. Kesesuaian ini merupakan kebutuhan untuk mempertahankan hidup dan menghindari resiko atas peran narasumber di tempat kerjanya. Hal ini sesuai dengan pendapat Porter dan Miles dalam Rivai (2005) bahwa faktor yang berpengaruh pada motivasi seseorang adalah ciri-ciri pribadi (Individual characteristics), tingkat dan jenis pekerjaan (Job characteristics), dan lingkungan kerja (Work situation characteristics). Kesesuaian tupoksi dan latar belakang pendidikan pada narasumber dapat membangkitkan motif yang kuat untuk melaksanakan aktivitasnya dalam mengelola tanaman obat. Hal ini sesuai dengan pendapat Morgan (1986: 269): "Motif adalah suatu potensi atau kekuatan dalam diri individu yang mendorong individu tersebut melakukan suatu tindakan, selaras dengan kebutuhan yang ada pada dirinya".

Faktor sosiopsikologis narasumber berkaitan dengan pengelolaan tanaman obat, yaitu bahwa tanaman obat merupakan tanaman yang dapat dimanfaatkan untuk pertolongan pertama, sumber pendapatan, dan sumber pangan keluarga, dapat dimanfaatkan sebagai sumber gizi keluarga, sehingga Toga harus disosialisasikan. Faktor sosiopsikologis ini mencerminkan sikap narasumber terhadap tanaman obat.

Menurut Rakhmat (1988), sikap memiliki tiga komponen, yaitu komponen kognitif yang 
merupakan aspek intelektual yang berkaitan dengan apa yang diketahui manusia, komponen afektif yang merupakan aspek emosional dari faktor sosiopsikologis, dan komponen konatif yang berhubungan dengan kebiasaan dan kemauan bertindak. Terbentuknya ketiga komponen pada dirinarasumbermerupakan hasil interaksi dirinya dengan lingkungan sosialnya. Salah satu lingkungan yang berkontribusi pada pembentukan ketiga komponen tersebut adalah lingkungan pendidikan yang dialami narasumber.

Menurut William Kornblum, pendidikan sebagai pranata sangat penting untuk membentuk kepribadian seseorang. Melalui pendidikan, seseorang akan lebih mampu menyesuaikan diri dengan perubahan yang terjadi dan memiliki wawasan yang luas sehingga tujuan hidup akan tercapai (Definisi: 2013).

Faktor sosiogenis dari narasumber menunjukkan bahwa mengelola tanaman obat bukan pengalaman baru, mendapatkan respon positif, antusiasme tinggi, sesuai dengan bidang ilmu, dan menjadi jaminan dalam bertugas. Hal ini sesuai dengan motif yang dikemukakan oleh W.I. Thomas dan Florian Znaniecki dalam Rakhmat (1988: 1) yaitu: keinginan memperoleh pengalaman baru, 2) keinginan untuk mendapat respons, 3) keinginan akan pengakuan, dan 4) keinginan akan rasa aman.

Pengalaman baru, mendapat respons positif, menimbulkan antusiasme tinggi, sesuai dengan bidang ilmu, dan menjadi jaminan dalam bertugas muncul sebagai konsekuensi dari interaksinya dengan masyarakat. Hal ini sesuai dengan motif sosiogenis yang dikemukakan oleh Sherif dan Sherif (1956) bahwa "Motif ini timbul karena perkembangan individu dalam tatanan sosialnya dan terbentuk karena hubungan antar pribadi, hubungan antar kelompok atau nilai-nilai sosial dan pranatapranata".

\section{SIMPULAN}

Faktor personal yang mendasari keterlibatan narasumber dalam pengelolaan toga di Jawa
Barat dilihat dari faktor biologis adalah karena sesuai dengan tugas pokok dan fungsi di mana mereka bertugas, dan didasarkan pada latar belakang pendidikannya di bidang pertanian, sehingga dapat membangun motivasinya untuk mengelola tanaman obat.

Dari faktor psikologis, menurutnya toga dapat dimanfaatkan untuk pertolongan pertama, sebagai sumber pendapatan keluarga, sebagai sumber gizi keluarga, oleh karena itu toga harus disosialisasikan kepada masyarakat.

Dari faktor sosiogenis, mengelola toga bagi narasumber bukan pengalaman baru, sehingga ketika mereka bertugas masyarakat merespons positif dan sangat antusias. Hal ini disebabkan apa yang dilakukan narasumber sesuai dengan bidang ilmunya dan menjadi jaminan dalam bertugas.

Penelitian ini masih belum sempurna dalam mengungkap realitas diri narasumber sebagai pengelola tanaman obat, oleh karena itu, penulis sarankan untuk melakukan kajian lebih dalam tentang etos kerja narasumber ketika dirinya melakukan aktivitasnya dalam mensosialisasikan tanaman obat, sehingga dapat diketahui efektivitas komunikasi yang dilakukannya.

\section{DAFTAR PUSTAKA}

Definisi. (2013). Klasifikasi pranata sosial. Diakses dari http://definisi.org/klasifikasipranata-sosial tanggal 6 maret 2013

Rakhmat, J. (1988). Psikologi komunikasi. Bandung: Remaja Karya.

Rivai, H. A. (September- Desember 2005). Pengaruh kompensasi, komitmen organisasional, dan kompetensi terhadap kinerja invidual. Kajian bisnis. Vol.3, 272-286.

Sherif, M., \& Sherif, C. W. (1956). An outline of social psychology. New York: Harper \& Row.

Morgan, C. T., King, R. A., Weisz, J. R., \& Schopler, J. (1986). Intoduction to psychology. Toronto: Mc Graw-Hill. 